\title{
Obituaries
}

\section{Anne Turner}

British family planning doctor whose assisted suicide in a Swiss clinic refuelled UK euthanasia debate

Anne Turner's final trip to continental Europe was one she resented having to make. She loved travelling to Europe, often for the opera. But having decided to kill herself, she felt frustrated at the need to leave the comfort of her cosy bungalow in Bath. However, with typical self assurance, Dr Turner made precise plans. She would die in Switzerland on 24 January 2006, the day before her 67 th birthday.

Events early in the childhood of the woman dubbed "Boadicea" by a friend can probably be credited for the independence and strength of character that she exhibited throughout her life. Just 18 months after her birth in Harrogate in 1939, she was evacuated, with her sister, from war torn Europe to Vancouver in Canada.

She only just made it. A German U boat sank the vessel behind the one in which she was travelling and such evacuations promptly ceased. But having safely reached North America, she enjoyed living with cousins and a grandmother.

In 1945 however, she returned to Westerham, Kent, in England and to parents she didn't know-and to the austere, postwar landscape. She would later joke that it felt as if she had been evacuated to the United Kingdom rather than returned home. After her carefree existence in Canada, the grey skies, food rations, and lack of central heating did not endear her to her native land.

Her father, a civil servant, and her mother, a local councillor, were strict and somewhat distant parents. So being packed off to boarding school in 1952 seemed more like a release than a frightening trip into the unknown.

Shortly after leaving school a lifethreatening adder bite provided a first glimpse of her mortality. Her response was not fear but curiosity. And from this near-death experience she decided that dying was as easy as going to sleep.

In 1958 she went to St Thomas' to study medicine. On the first day she met her future husband, Jack Turner. After qualifying, they worked in the south of England before settling in Bath, where they found jobs in general practice and began a family.

Anne Turner soon developed an interest in family planning, and was to play a key role

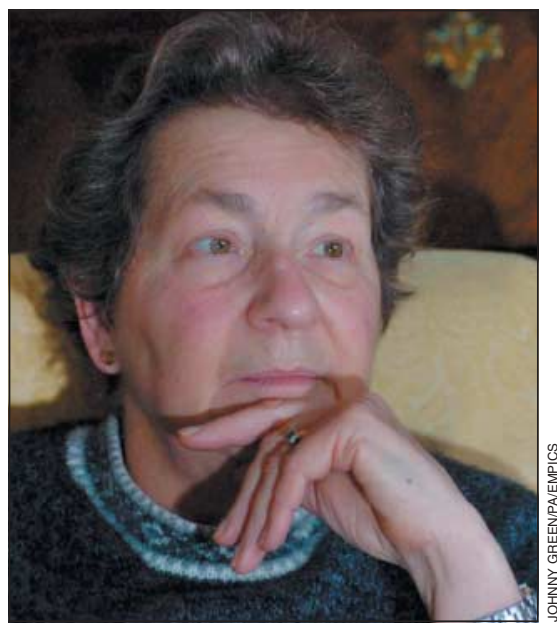

movement, speech, swallowing reflex, and blinking, as well as causing mood swings. People with PSP usually live for seven years. But she had other plans.

She told her children the diagnosis in November 2004 and in the same breath shocked them with the calm declaration that she would take her own life. Their attempts to talk their mother out of suicide were in vain. In October 2005 she tried but failed to take her own life with sleeping pills in her bungalow in Bath.

If Jack's situation three years earlier had been terrible, Anne's was worse. She had already seen her beloved husband die horribly. And unlike her husband, who was able to find pleasures and distractions in the smallest things, sounds, sights, and memories, Anne's more purposeful and resolute mindset allowed her to focus only on the immediate problem: her condition and how she might end it.

For Dr Turner, whose interest in medical and health screening for women in Bath for nearly 30 years. From 1991 she was a regional adviser in family planning training for the whole of the old Wessex health region. She helped found the Bath and Wiltshire Doctors Group, which provides postgraduate training in contraception and sexual health to practitioners locally.

She had little time for views at either extreme of the pro-life versus pro-choice debate. An atheist and pragmatist, she was frank about the trauma involved in abortion, but also believed that all women, including the socially disadvantaged, had the right to organise their lives and families in the way that suited their individual circumstances.

She had already been a supporter of the Voluntary Euthanasia Society for around 10 years when, in 1997, it was discovered that her husband, Jack, had multiple system atrophy. That year, at the age of 58 , she gave up work to care for him.

In the words of her son, Edward, Jack became a "breathing corpse." He died in September 2002. Anne Turner told her children that she never wanted to end up like her husband.

A series of falls in 2003 were the first symptoms of the degenerative condition that would strangle her will to live. The rare disease, called progressive supranuclear palsy, or PSP, would progressively affect her in the rights of the individual, her choice to end her own life was perfectly consistent. She believed passionately that assisted suicide should become legal. She said: "I don't think death has ever held any fear for me. I haven't got faith, I'm a humanist. I've always felt that dying is like going to sleep."

Anne Turner certainly gave the impression of not being a sentimental person. But speaking the week before her death, her self regard asserted itself alongside her concern for her children as she told them: "I don't want to be remembered by you as being totally incapacitated, which I will be."

So at $1205 \mathrm{pm}$ Greenwich Mean Time on 24 January, Dr Turner drank the barbiturates given to her in an anonymous Zurich apartment and slipped into a coma, dying 25 minutes later. She was the 42 nd Briton to die with the help of the group Dignitas.

She leaves three children. [MICHAEL DAY]

Anne Turner, family planning specialist Bath (b 1939; $q$ St Thomas'Hospital, London, 1962), d 24 January 2006.

Longer versions of these obituaries are available on bmj.com ethics had always stemmed from her belief 


\section{Alan Hamilton Cruickshank}

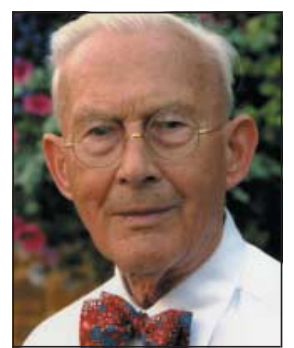

Former reader in pathology University of Liverpool (b 1913; q Aberdeen 1937;MD), died from pneumonia following a stroke on 7 November 2005.

Alan was a national authority on pancreatic and salivary gland disease. He was lecturer in pathology at Liverpool University in 1948 and subsequently senior lecturer and reader until 1978. After retirement he worked for the United Nations setting up a department of pathology in Kathmandu, Nepal, and, until his age disqualified him, as a pathologist in north west England. In his 90s he was still attending grand rounds at the Royal Liverpool Hospital and meetings at the Liverpool Medical Institution. He leaves three sons. [Robert Cruickshank]

\section{Peter Dally}

Former senior consultant psychiatrist Westminster Hospital,London (b 1923; q St Thomas' Hospital, London 1953; FRCP,FRCPsych, DPM), died from cancer on 25 June 2005.

Peter Dally was a midshipman from Dartmouth Royal Naval College at the start of the second world war and a full lieutenant by the end. Discharged in 1947 on medical grounds, he then studied medicine. During his first psychiatric appointment in 1955 he only partially recovered from severe polio paralysis but became house physician and research registrar to William Sargant, the best known psychiatrist of the time. Peter's special interest was anorexia nervosa and bulimia. Westminster Hospital founded the Peter Dally Clinic for Eating Disorders on his retirement. Predeceased by two sons, he leaves four children. [ANN DALLY]

\section{Advice}

We will be pleased to receive obituary notices of around 250 words. Pressure on space means that in most cases we will be able to publish only about 100 words in the printed journal, but we can run a fuller version on our website. We will take responsibility for shortening. We do not send proofs. Good quality, original photographs are welcome. Please give a contact telephone number and, where possible, supply the obituary on a diskorbyemail to obituaries@bmj.com If sending a picture electronically, please attach as a jpeg or a tiff rather than as part of a Word document. We need to know the year of birth and exact date of death of the deceased, and we prefer obituaries to state the cause of death. Please spell out abbreviations.

\section{David Shaw Dick}

Former general practitioner Strathpeffer (b 1912; q Edinburgh 1938; BSc, DA), d 13 October 2005.

After various house jobs in the Stockton area David joined the Royal Army Medical Corps in 1940. He served with field ambulance units at the Battle of Alamein and participated in the landings at Salerno and Anzio, where he was mentioned in dispatches. After demobilisation he joined the blood transfusion services for the Midlands, based in Birmingham. In 1947 David took over the Strathpeffer Medical Practice. He gave anaesthetics at the Inverness hospitals, Dingwall Hospital, and for local dentists until he retired in 1977. Predeceased by his wife, Sheila, he leaves two daughters and five grandsons. [MARGARET NEWTON]

\section{Douglas Francis Freebody}

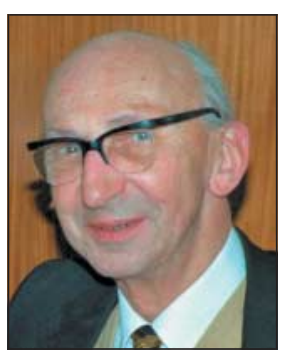

Former consultant orthopaedic surgeon Kingston Hospital (b 1911; q Guy's Hospital, London, 1936; FRCS), died from heart failure on 12 October 2005.

Douglas Freebody made an important contribution to orthopaedics and spinal surgery. National service with the Royal Army Medical Corps (1946-48) took him to Egypt and Palestine, and gained him a mention in dispatches. At Kingston Hospital he developed his technique of anterior fusion for spondylolisthesis using an iliac bone graft with a transperitoneal approach. Douglas was a keen gardener and an expert on orchids. He leaves a wife, Yvonne, his children and grandchildren. [BARRIE PARKER]

\section{Patrick Huck}

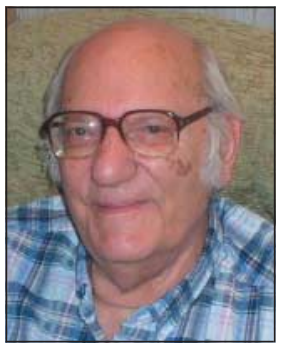

Former consultant oncologist Sheffield (b 1918; $q$ Edinburgh 1942), died from carcinomatosis on 11 Norvember 2005.

Patrick Huck pursued his interest in oncology by taking up senior radiotherapy posts in Auckland Hospital, New Zealand, and St Vincent's Hospital, Sydney. On returning to the United Kingdom 20 years later, in 1970 , he was promptly invited to help develop a new oncology unit in Tawam Hospital in Abu Dhabi, United Arab Emirates, where he worked for four years. In 1974 he became consultant oncologist at Weston Park Hospital, Sheffield, retiring in 1988. He leaves a wife, Evelyn; six children; and seven grandchildren. [GERALD SANDLER]

\section{Ian Macalister}

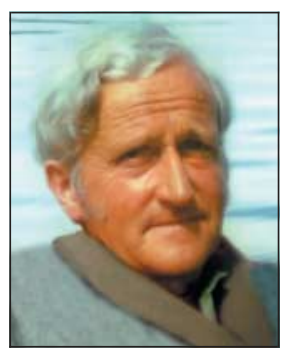

Former general practitioner Hawick,

Roxburghshire (b 1916; q Edinburgh 1942), died from Parkinson's disease on 17 December 2005.

After war service in the Royal Army Medical Corps in North Africa and Italy Ian was offered a partnership in Hawick in 1948, just as the NHS was established. A keen gardener, Ian would often be seen during his early years working in the garden on his half day with his prescription pad and pen on the wall beside him, for patients passing by would think nothing of asking him for a repeat prescription. He leaves a wife, Sheila; two sons; and three grandchildren. [P N Paterson-Brown, D A Buchanan]

\section{Jacob Mackinnon}

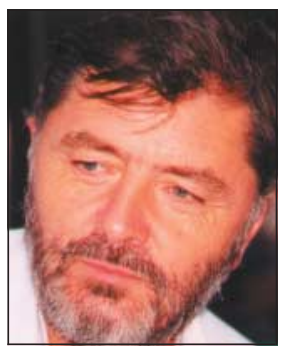

Paediatrician in private practice London (b London 1946; q St Bartholomew's Hospital, London, 1970; FRCP, FRCPCH), died from a dissecting aortic aneurysm on 5 April 2005. Jake held a series of prestigious London training posts in paediatrics before taking up consultant posts at Sydenham Children's Hospital and Farnborough Hospital, Bromley, in 1980. Ten years later he moved into full time private practice, where he forged a formidable clinical service for children that blended biomedical and psychological principles. His fluent French enabled him to manage clinical cases jointly with French colleagues. He leaves a wife, Elizabeth, and three children. [Peter Hill] 